\title{
Two New Species of Hedysarum (Fabaceae) from Iran
}

\author{
Massoud Ranjbar \\ Department of Biology, Herbarium Division, Bu-Ali Sina University, P.O. Box 65175/4161, \\ Hamedan, Iran. ranjbar@basu.ac.ir
}

Aвstract. Hedysarum orumiehense Ranjbar and $H$. neyshaboricum Ranjbar, two new species endemic to Iran, are described and illustrated. Both new species belong to section Multicaulia Boiss. in Hedysarum L. (Fabaceae) and are distinct among Iranian species. The former species is closely related to $H$. atropatanum Bunge ex Boiss. and is distinguished by its glabrous pods, the leaflets in eight to 11 pairs, and the longer corolla wings $(10-11 \mathrm{~mm})$. The latter is distinguished from $H$. paucifoliolatum Ranjbar \& Olanj by its longer peduncles $(20-27 \mathrm{~cm})$, stipules (7$9 \times 4-5 \mathrm{~mm})$, and corolla standard (15-17 $\times 13-$ $14 \mathrm{~mm})$. Both $H$. orumiehense and H. neyshaboricum are evaluated as Vulnerable (VU) according to IUCN Red List criteria.

Key words: Fabaceae, Hedysarum sect. Multicaulia, Iran, IUCN Red List.

Hedysarum L., with ca. 200 species, is a large genus within the tribe Hedysareae (Fabaceae) and is distributed in temperate to boreal regions of the Northern Hemisphere (Vassiljeva, 1987). The main centers of diversity are in Middle Asia and North America, but the genus also occurs in Europe and the Mediterranean region (Yakovlev et al., 1996; Ranjbar et al., 2007a, b). Plants of the genus are perennial herbs, rarely semishrubs, and they occur in varied habitats including alpine and arctic meadows, stony grasslands, deserts, or seashores (Ranjbar et al., $2007 \mathrm{a}, \mathrm{b})$. The flora of Iran is relatively rich in Hedysarum species with 28 species, of which 16 are endemic (Rechinger, 1984; Ranjbar et al., 2004, 2006, 2007a, b), and new Hedysarum taxa have been described recently for Iran (Ranjbar et al., 2004, 2006). In October 2005, I made an expedition to the Silvaneh range near Orumieh, in western Iran, an area adjacent to eastern Turkey. During field collection, the specimen Ranjbar 7092 was initially identified as H. atropatanum Bunge ex Boiss. However, its glabrous pod and many leaflets distinguish it from $H$. atropatanum, which has an appressed pubescent pod. As a result, the new species $H$. orumiehense Ranjbar (Fabaceae) is described here. A second new species, H. neyshaboricum Ranjbar, also described here, differs from $H$. paucifoliolatum Ranjbar \& Olanj by having longer peduncles and flowers.
1. Hedysarum orumiehense Ranjbar, sp. nov. TYPE: Iran. Azarbaijan Garbi: Orumieh, ShahrChai dam, near Band, 1530 m, 11 June 2005 (fl., fr.), M. Ranjbar 7092 (holotype, BASU; isotypes, FUMH, MO, TARI, W). Figure 1.

Haec species Hedysaro atropatano Bunge ex Boiss. affinis, sed ab eo foliolis 8- ad 11- (nec 4- ad 6-) jugatis, racemo 22- ad 33- (nec 10- ad 15-) floro, petalis longioribus vexillo $17-18 \mathrm{~mm}$ (nec 14-15 mm) alis 10$11 \mathrm{~mm}($ nec $3-4 \mathrm{~mm}$ ) atque legumine aculeis flavorubris dense obtecto differt.

Plants to $40 \mathrm{~cm}$ tall, with numerous wiry stems from a tough rootstock, appressed pubescent; stems branched only from near the base; caudex to $5 \mathrm{~mm}$ diam. Stipules 5-6 × 4-5 mm, light brown, slightly connate on the side opposite to the leaves, the lower ones triangular, the upper narrowly triangular and acuminate, adnate to the petiole for $1-1.5 \mathrm{~mm}$, sparsely to loosely covered with appressed white trichomes (ca. $0.3 \mathrm{~mm}$ ); leaves imparipinnate, 6.5$11.5 \mathrm{~cm}$; petioles of lower leaves $10-11.5 \mathrm{~cm}$, those of upper leaves often shorter, to $5 \mathrm{~mm}$ long, subdensely to loosely covered with appressed white trichomes; leaflets in 8 to 11 pairs, oblong to lanceolate or elliptic, rarely obovate, 8-18 $\times 3-$ $9 \mathrm{~mm}$, apex obtuse to rounded, mostly shortly mucronulate, densely appressed pubescent abaxially (trichomes ca. $0.5 \mathrm{~mm}$ ), grayish, adaxially densely to sparsely appressed pubescent (trichomes $0.5-1 \mathrm{~mm}$ ), green. Inflorescence a dense raceme of 22 to 33 flowers, oblong-ovate, elongating in fruit to $28 \mathrm{~cm}$; peduncles $12.5-15.5 \mathrm{~cm}, 1-1.5 \mathrm{~mm}$ thick, erect to ascending, exceeding the leaves, densely to loosely appressed pubescent (trichomes ca. $0.5 \mathrm{~mm}$ ); bracts 3-3.3 × ca. $1 \mathrm{~mm}$, linear-lanceolate, membranous; pedicels 2-3 mm, appressed pubescent. Flowers erect to slightly spreading to nodding; bracteoles linear, shorter than the calyx tube, ca. $1.5 \mathrm{~mm}$, loosely covered by short appressed trichomes; calyx 6-7 mm, tubular-campanulate, densely covered with short appressed white trichomes (ca. $0.3 \mathrm{~mm}$ ); calyx teeth narrowly linear to subulate, $3-5 \mathrm{~mm}$; corolla flushed with mauve, standard 17-18 mm, blade 9$10 \mathrm{~mm}$ wide, obovate, apex slightly emarginate, gradually attenuate to the base, wings lingulate, 


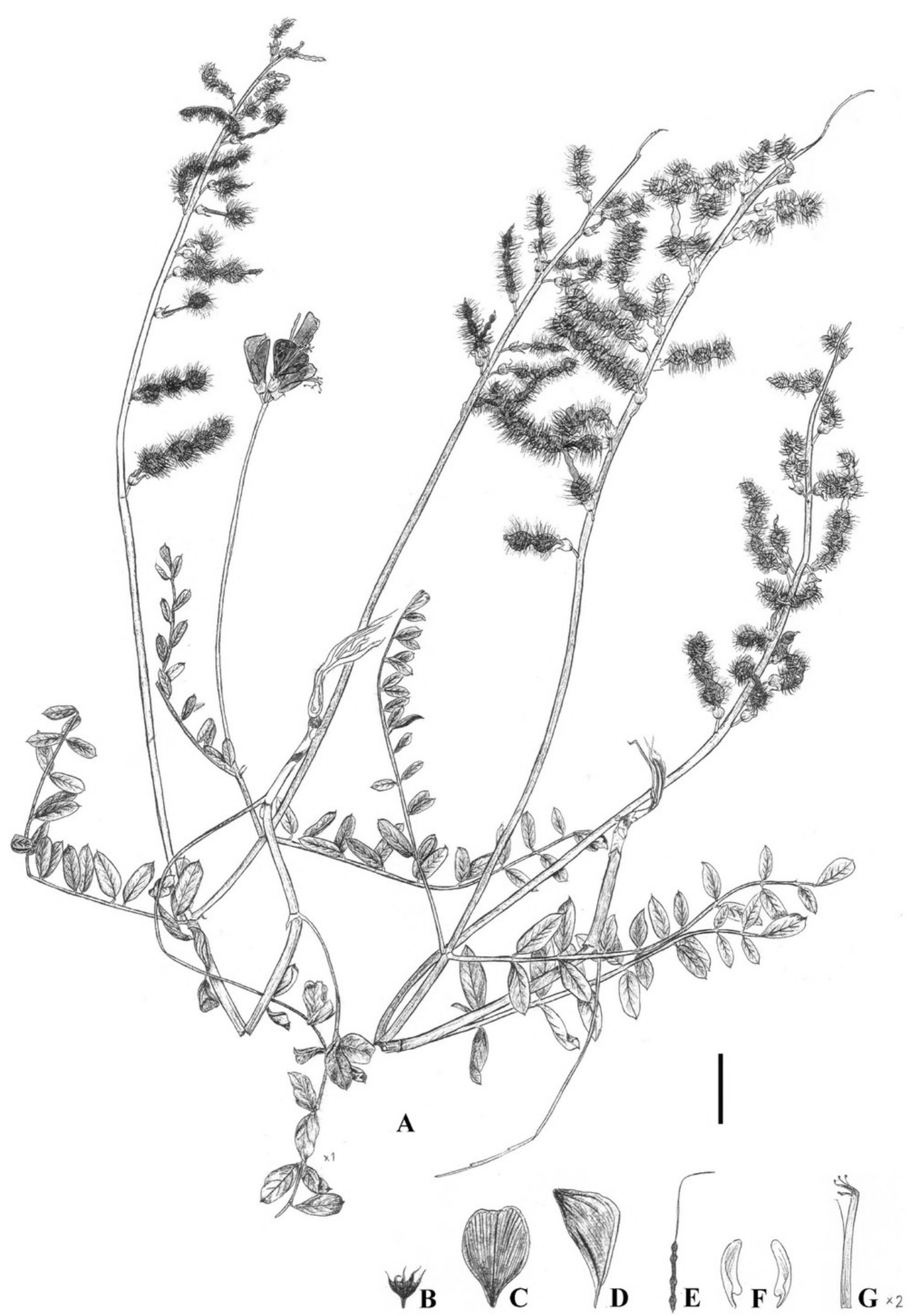

Figure 1. Hedysarum orumiehense Ranjbar. -A. Fertile habit. —B. Calyx. —C. Standard. —D. Keel. —E. Immature pod. -F. Wings. -G. Androecium. Drawn from the holotype Ranjbar 7092 (BASU). Scale bar: A = $3 \mathrm{~cm}$; B-G = $1.5 \mathrm{~cm}$.

shorter than the standard, 10-11 $\mathrm{mm}$, apex rounded to subobtuse; blades 6-7 $\times 2.5-3 \mathrm{~mm}$; claw 2.5$3 \mathrm{~mm}$, keel 18-19 mm, \pm equaling the standard; blades subtriangular, $13-14 \times 6-7 \mathrm{~mm}$, obtuse at the apex; auricle indistinct, claw 4-5 mm, staminal tube obliquely cut; ovary linear, short white appressed pubescent; style glabrous. Legumes immature, 3 - to 5-jointed, linear, straight, densely covered with 
yellowish red prickles, but without appressed white trichomes or only densely pubescent at margin.

Distribution and habitat. Hedysarum orumiehense has a restricted distribution. It occurs on the eastern slope of the Silvaneh and Razhan mountains in West Azerbaijan Province, Iran. It was collected from a small population growing on dry steppe and stony clay along the roadside.

IUCN Red List category. Hedysarum orumiehense is known only from the type locality, where one small population consisting of no more than 20 plants was observed sparsely scattered near a small village. Therefore, this species is classified as Vulnerable (VU), a category that includes taxa with small populations that could be at risk, according to IUCN Red List criteria (IUCN, 2001).

Phenology. Flowering occurs in May and June; fruit ripening occurs from June to August.

Etymology. The new species is named after the type locality, the town of Orumieh, in West Azerbaijan Province, Iran.

Taxonomic relationships. Although I have not seen the type of Hedysarum atropatanum at W, the original description agrees in all respects with the material for Ranjbar 6090 (BASU), which is from the type locality Seidkhodzi near Khoy (Boissier, 1872; Rechinger, 1984). In addition, H. atropatanum is the only other species of Hedysarum sect. Multicaulia Boiss. known from the Iranian province of West Azerbaijan. Hedysarum orumiehense was seen in the field by the author and is known from only five specimens from the type locality that are deposited at BASU.

The new species is closely related to Hedysarum atropatanum in the similar shape, size, and indumentum of the leaflets and in the stipules, which are connate on the side opposite to the leaves in both species. Hedysarum orumiehense differs from $H$. atropatanum by its larger corolla $(17-18 \mathrm{~mm}$ vs. $14-15 \mathrm{~mm})$ and wings $(10-11 \mathrm{~mm}$ vs. $3-4 \mathrm{~mm})$, the densely yellowish red aculeate vs. white aculeate legumes, the greater number of leaflets (eight to 11 vs. four to six), and the more densely flowered axillary racemes (22- to 33 -flowered vs. $10-$ to $15-$ flowered).

2. Hedysarum neyshaboricum Ranjbar, sp. nov. TYPE: Iran. Khorasan: $\mathrm{N}$ of Neyshabor, around Abshar, Bar village, 1850-1900 m, 20 May 1996, A. Rafeie \& H. Zangooei 27013 (holotype, FUMH; isotype, BASU). Figure 2.
Haec species Hedysaro paucifoliolato Ranjbar \& Olanj affinis, sed ab eo plantis $45-50 \mathrm{~cm}$ (nec usque ad $35 \mathrm{~cm}$ tantum) altis, stipulis 7-9 $\times 4-5 \mathrm{~mm}$ (nec 5-6 $\times 2-3 \mathrm{~mm}$ ), foliis 11-14 cm (nec 3.5-6.5 cm) longis, foliolis 2- ad 4(nec 1- vel 2-[vel 3-]) jugatis, pedunculo 20-27 cm (nec 7-10 cm) longo, racemo 22- ad 30- (nec 10- ad 15-) floro, petalis majoribus vexillo $15-17 \times 13-14 \mathrm{~mm}($ nec $10-11$ $\times 7-8 \mathrm{~mm}$ ) alis $7-8 \mathrm{~mm}$ (nec $4-5 \mathrm{~mm}$ ) longis atque ovario glabro (nec trichomatibus albis appressis dense vestito) differt.

Plants to $50 \mathrm{~cm}$ tall, with numerous stems from a tough rootstock, appressed pubescent; stems 9-19 cm, branched from near the base; caudex to $1 \mathrm{~cm}$, covered with stipule and petiole remnants. Stipules $7-9 \times 4-$ $5 \mathrm{~mm}$, light brown to membranous, semiconnate, the lower ones triangular, the upper narrowly triangular and acuminate from a wide base, adnate to petiole for 2$3 \mathrm{~mm}$, sparsely to loosely covered with appressed white trichomes (0.5-0.8 mm); leaves imparipinnate, 11$14 \mathrm{~cm}$; petioles of lower leaves $2.9-4.5 \mathrm{~cm}$, those of upper leaves often shorter, $0.8-2.5 \mathrm{~cm}$, densely to loosely covered with appressed white trichomes; leaflets in 2 to 4 pairs, ovate-lanceolate, $20-55 \times 10-34 \mathrm{~mm}$, apex obtuse to round or rarely slightly retuse, mostly shortly mucronulate, loosely to sparsely appressed pubescent abaxially $(0.4-1 \mathrm{~mm})$, green to grayish green, adaxially loosely to sparsely appressed pubescent. Inflorescence a dense raceme of 22 to 30 flowers, oblong-ovate; peduncles $20-27 \times 0.25-0.4 \mathrm{~cm}$, erect to ascending, exceeding the leaves, densely to loosely appressed pubescent (trichomes $0.2-0.6 \mathrm{~mm}$ ); bracts 5$6 \mathrm{~mm}$, linear-lanceolate, membranous to papery, apex purplish; pedicels $2-3 \mathrm{~mm}$, appressed pubescent, the upper flowers often sessile. Flowers erect to spreading; bracteoles shorter than the calyx tube, glabrous to sparsely covered by short appressed trichomes; calyx 6$7 \mathrm{~mm}$, tubular-campanulate, densely covered by short appressed white trichomes $(0.4-0.7 \mathrm{~mm})$; calyx teeth narrowly linear to subulate, $3-5 \mathrm{~mm}$; corolla dark purple, standard 15-17 mm, blade 13-14 mm wide, obcordate, apex deeply emarginate, gradually attenuate to the base, glabrous, wings lingulate, shorter than the standard and keel, 7-8 mm, apex rounded; blades 5-6 $\times$ ca. $3 \mathrm{~mm}$; auricle shorter than claw, claw ca. $2 \mathrm{~mm}$, keel 13-14 mm, exceeding the wings; keel blades subtriangular, 10-11 × 7-7.5 mm, apex subacute; auricle indistinct, claw ca. $4 \mathrm{~mm}$; staminal tube obliquely cut; ovary with a stipe $0.5-1 \mathrm{~mm}$, with 4 or 5 ovules, linear, glabrous; style glabrous. Legumes not seen.

Distribution and habitat. Hedysarum neyshaboricum is a narrowly distributed endemic known only from the dry zone of the mountainous region near Abshar, Bar village, north of Neyshabor in Khorasan Province, Iran, growing on limestone and stony clay substrates. 


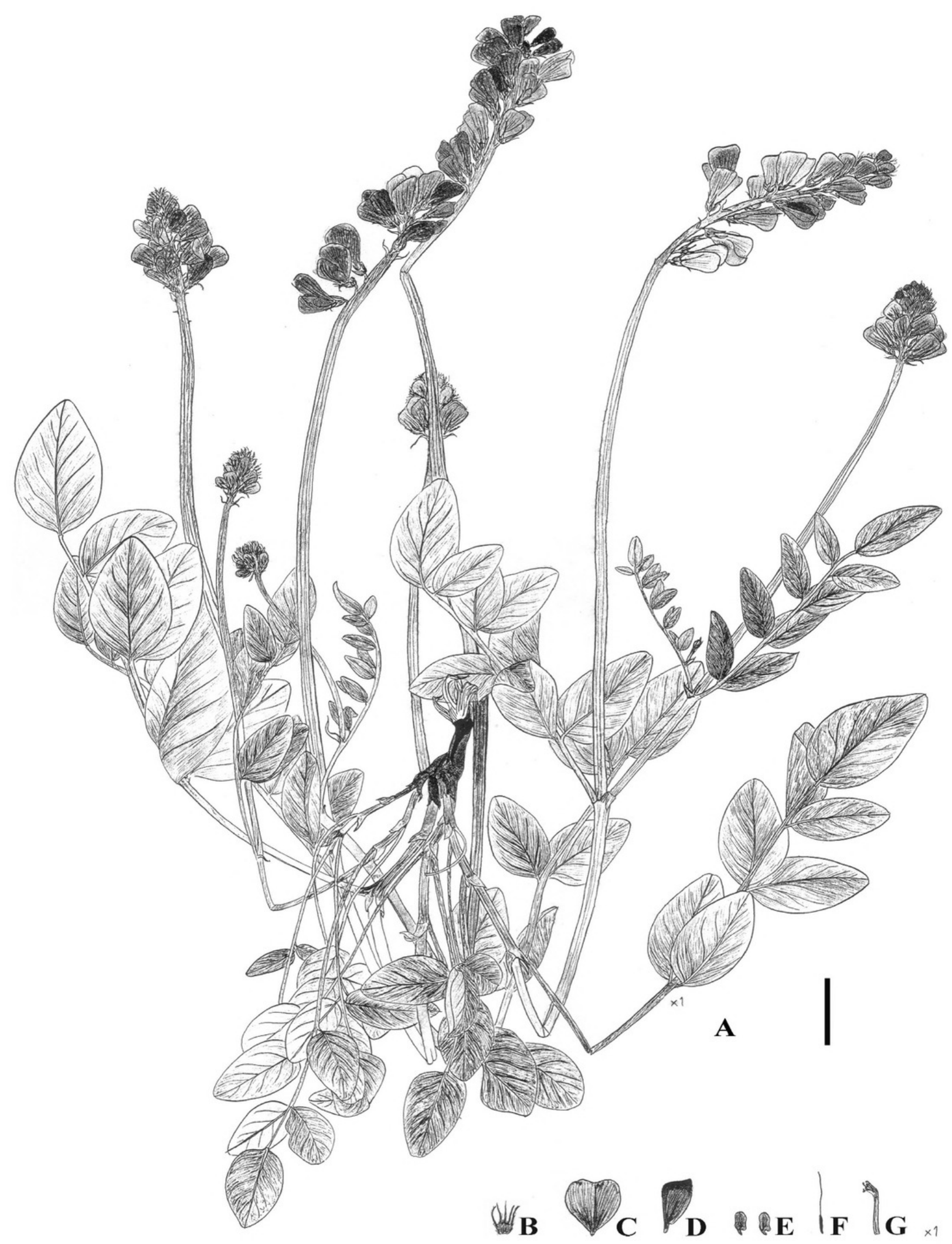

Figure 2. Hedysarum neyshaboricum Ranjbar. - A. Habit with details of flower and pod. —B. Calyx. —C. Standard. —D. Keel. -E. Wings. -F. Pistil. —G. Androecium. Drawn from the holotype Rafeie \& Zangooei 27013 (FUMH). Scale bar: A = $3 \mathrm{~cm} ; \mathrm{B}-\mathrm{G}=1.5 \mathrm{~cm}$.

IUCN Red List category. The type locality of the new species is the unprotected Binalood mountainous region; therefore, Hedysarum neyshaboricum is assessed here as Vulnerable (VU) according to IUCN Red List criteria (IUCN, 2001). The conservation status cannot be more precisely determined because this species is known only from a single collection. 
Phenology. Hedysarum neyshaboricum has been collected in flower from May to June.

Etymology. The species is named after the type locality, the town of Neyshabor, in Khorasan Province, Iran.

Taxonomic relationships. The similar shape and number of leaflets confirm a close relationship between Hedysarum neyshaboricum and $H$. paucifoliolatum. The two taxa are similar in their ovate to ovate-lanceolate leaflets and similarly sized bracts and calyces. However, the new species differs by having a glabrous ovary (vs. densely short-appressed, white indument), a longer peduncle (20-27 cm vs. 7$10 \mathrm{~cm})$, more densely flowered inflorescences (22- to 30-flowered vs. 10- to 15-flowered), and a larger corolla standard $(15-17 \times 13-14 \mathrm{~mm}$ vs. $10-11 \times 7$ $8 \mathrm{~mm}$ ) with a longer wing $(7-8 \mathrm{~mm}$ vs. $4-5 \mathrm{~mm})$. Furthermore, plants range to $50 \mathrm{~cm}$ in $H$. neyshaboricum (vs. to $35 \mathrm{~cm}$ in $H$. paucifoliolatum) and leaf blades are longer (11-14 cm vs. $3.5-6.5 \mathrm{~cm})$. Measurements for $H$. paucifoliolatum are taken from the holotype.

Acknowledgments. I appreciated help from Ernst Vitek, Bruno Wallnöfer, and Walter Till during my visit to $\mathrm{W}$ and $\mathrm{WU}$ in Vienna. I thank the Director of the Herbarium of the Research Institute of Forests and Rangelands (TARI); Herbarium of Ferdowsi University (FUMH), Mashhad; and the Herbarium Research Centers of Natural Resources and Animal Affairs of Tabriz, Mashhad, Esfahan, Shiraz, Kerman, and Zahedan for making the herbarium facilities available for my study. I am grateful to Victoria Hollowell, Beth Parada, and Allison Brock (MO) for revising the manuscript, as well as for their useful comments and suggestions. I also thank Roy Gereau for checking the Latin and Mitra Hezarkhani for preparing the illustrations.

\section{Literature Cited}

Boissier, P. E. 1872. Hedysarum. Pp. 522-523 in P. E. Boissier (editor), Flora Orientalis, Vol. 2. H. Georg, Geneva.

IUCN. 2001. IUCN Red List Categories and Criteria, Version 3.1. Prepared by the IUCN Species Survival Commission. IUCN, Gland, Switzerland, and Cambridge, United Kingdom.

Ranjbar, M., H. Amirabadizadeh, R. Karamian \& M. A. Ghahremani. 2004. Notes on Onobrychis sect. Heliobrychis (Fabaceae) in Iran. Willdenowia 34: 187-190.

, R. Karamian \& M. R. Johartchi. 2006. Notes on the taxonomy of Hedysarum (Fabaceae) in Iran. Ann. Bot. Fenn. 43: 152-155.

$\longrightarrow$, Z. Tolui \& H. Amirabadizadeh. 2007a. Onobrychis assadii (Fabaceae), a new species from Iran. Ann. Bot. Fenn. 44: 481-484.

—— \& N. Olanj. 2007b. A new species of Hedysarum (Fabaceae) in Iran and other new Hedysarum records. Bot. J. Linn. Soc. 155: 505-512.

Rechinger, K. H. 1951. Papilionaceae novae iranicae. Bot. Jahrb. Syst. 75: 338-339. . 1984. Hedysarum. Pp. 366-386 in K. H. Rechinger (editor), Flora Iranica, Vol. 157. Akademische Druck und Verlagsanstalt, Graz.

Vassiljeva, L. I. 1987. In Flora Partis Europaea URSS, Vol. 6. Leningrad.

Yakovlev, G. P., A. K. Sytin \& J. R. Roskov. 1996. Legumes of Northern Eurasia, a Check-list. Royal Botanic Gardens, Kew, Richmond. 


\section{$2 \mathrm{BHL}$ Biodiversity Heritage Library}

Ranjbar, Massoud. 2010. "Two New Species of Hedysarum (Fabaceae) from Iran." Novon a journal of botanical nomenclature from the Missouri Botanical Garden 20, 329-333.

View This Item Online: https://www.biodiversitylibrary.org/item/123332

Permalink: https://www.biodiversitylibrary.org/partpdf/122034

\section{Holding Institution}

Missouri Botanical Garden, Peter H. Raven Library

\section{Sponsored by}

Missouri Botanical Garden

\section{Copyright \& Reuse}

Copyright Status: Permission to digitize granted by rights holder Rights: https://www.biodiversitylibrary.org/permissions

This document was created from content at the Biodiversity Heritage Library, the world's largest open access digital library for biodiversity literature and archives. Visit BHL at https://www.biodiversitylibrary.org. 